Article

\title{
Facing the Issues Raised in Psalm 1 through Thinking and Feeling: Applying the SIFT Approach to Biblical Hermeneutics among Muslim Educators
}

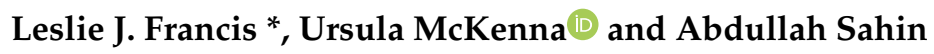 \\ Centre for Education Studies, University of Warwick, Coventry CV4 7AL, UK; \\ U.McKenna@warwick.ac.uk (U.M.); A.Sahin@warwick.ac.uk (A.S.) \\ * Correspondence: Leslie.Francis@warwick.ac.uk: Tel.: 024-7652-2539
}

Received: 5 July 2018; Accepted: 23 July 2018; Published: 21 October 2018

check for updates

\begin{abstract}
A group of 22 Muslim educators participating in a residential Islamic Education summer school were invited to explore their individual preferences for thinking and feeling (the two functions of the Jungian judging process). They were then invited to work in three groups (seven clear thinking types, eight clear feeling types, and seven individuals less clear of their preference) to discuss Psalm 1. Clear differences emerged between the ways in which thinking types and feeling types handled the judgement metred out to the wicked in the Psalm. The feeling types were disturbed by the portrayal of God in Psalm 1 and sought ways to mitigate the stark message. The thinking types confronted the dangers to which this image of God could lead and sought pedagogic strategies for dealing with these dangers.
\end{abstract}

Keywords: biblical hermeneutics; Muslim educators; Islamic education; reader perspective; psychological type theory

\section{Introduction}

Carl Jung's model of the human psyche suggests that human mental functioning is shaped by two core processes. Jung styles one of these processes the perceiving process. This is the irrational process concerned with the gathering of information. According to Jung's binary model of mental functioning, the perceiving process operates through the two functions of sensing and intuition. Sensing types build up their picture of the world by giving attention to the details and sensory data. Intuitive types build up their picture of the world by giving attention to the patterns, theories and ideas sparked by the data. As a consequence, sensing types and intuitive types construct somewhat different views of the world. Jung styles the other process the judging process. This is the rational process concerned with the evaluation of information. According to Jung's binary model of mental functioning, the judging process operates through the two functions of thinking and feeling. Thinking types evaluate situations through the application of impersonal objective analysis. Feeling types evaluate situations through the application of personal and interpersonal values. As a consequence, thinking types and feeling types construct somewhat different evaluations of situations. Jung's basic ideas about these two core psychological processes at the centre of human mental functioning were set out in his classic book on Psychological Type (Jung 1971) and have been expanded and developed through the various mechanisms devised to assess psychological type profiles and to test psychological type theories, like the Myers Briggs Type Indicator (Myers and McCaulley 1985).

Psychological type theory was introduced to the field of biblical hermeneutics and liturgical preaching in a systematic way by Francis (1997). This study worked through key passages from Mark's Gospel exploring ways of reading each passage in four sequential steps drawing first on the 
two perceiving functions (sensing and intuition) and then on the two judging functions (feeling and thinking). This approach was taken further in three volumes by Francis and Atkins (2000, 2001, 2002) intended to explore whether the approach was sustainable throughout the Principal Sunday Gospel readings proposed by the three year cycle of the Revised Common Lectionary. This approach, known as the SIFT method of biblical hermeneutics and liturgical preaching, was located more fully within the reader perspective approach to biblical hermeneutics by Francis and Village (2008).

The reader perspective approach to biblical hermeneutics, as displayed for example by Segovia and Tolbert (1995a, 1995b), was grounded initially in drawing on sociologically-shaped categories as reflected in feminist readings (Schottroff and Wacker 2012), black readings (Brown 2004) and liberation readings (Botta and Andiňach 2009). The point made by Francis and Village (2008) was that distinctive reader perspectives were shaped not only by the structural location of the reader but also by the psychological type profile of the reader.

The SIFT approach to biblical hermeneutics and liturgical preaching originated in extrapolation from psychological type theory. Subsequently a serious attempt has been made to test this theory empirically by listening carefully to the ways in which people of different psychological types generate distinctive readings when working together in type-alike groups. Typically, the empirical research takes place in a workshop environment. Participants first undertake type profile assessment and agree to work in groups of like-minded people. These groups of like-minded people have been constituted in three different ways: on the basis of the perceiving process distinguishing between sensing type and intuitive type; on the basis of the judging process distinguishing between feeling types and thinking types; on the basis of dominant type preferences distinguishing among dominant sensing types, dominant intuitive types, dominant feeling types, and dominant thinking types. The question addressed by the workshop is shaped according to the basis on which the group has been formed. Thus, groups distinguishing between sensing and intuition are invited to focus on a perceiving task, while groups distinguishing between feeling and thinking are invited to focus on an evaluating task. Groups distinguishing among the four dominant type preferences are invited to focus on a more general task that may draw on either perceiving or evaluating.

This approach has now been employed to explore the following passages of scripture: the feeding of the five thousand reported in Mark 6: 34-44 (Francis 2010); the resurrection narratives reported in Mark 16: 1-8 and Matthew 28: 1-15 (Francis and Jones 2011); the cleansing of the Temple and the incident of the fig tree reported in Mark 11: 11-21 (Francis 2012a; Francis and Siôn 2016a); the Johannine feeding narrative reported in John 6: 4-22 (Francis 2012b); the narrative of separating sheep from goats reported in Matthew 25: 31-46 (Francis and Smith 2012); the birth narratives reported in Matthew 2: 13-20 and Luke 2: 8-16 (Francis and Smith 2013); two narratives concerning John the Baptist reported in Mark 1: 2-8 and Luke 3: 2b-20 (Francis 2013; Francis and Smith 2014); the Johannine feeding narrative reported in John 6: 5-15 (Francis and Jones 2014); two passages from Mark exploring different aspects of discipleship reported in Mark 6: 7-14 and Mark 6: 33-41 (Francis and Jones 2015a); the foot washing account reported in John 13: 2b-15 (Francis 2015); two healing narratives reported in Mark 2: 1-12 and Mark 10: 46-52 (Francis and Jones 2015b); and the narrative of blind Bartimaeus reported in Mark 10: 46-52 (Smith and Francis 2016), the Road to Emmaus narrative reported in Luke 24: 13-35 (Francis and Siôn 2016b; Francis and Smith 2017), the call of the first disciples recorded in Luke 5:1-7 (Francis and Siôn 2017), and the missionary journey of the disciples in Mark 6: 6b-17 (Francis et al. 2017). More recently this research tradition has also been developed in Poland by Chaim (2013, 2014, 2015).

The cumulative evidence emerging from these studies is consistent and persuasive and can be summarised succinctly by the following five main points. First, when participants are discussing sacred text in 'type-alike' groups (in which all participants hold in common a clear preference for the same psychological type function), this concentration of a specific type preference allows the distinctive voice of that preference to emerge with clarity. Theory suggests that this is the case because the participants are seeing things or evaluating matters in a like-minded way. In the absence of significant challenges 
being posed from the opposing psychological type function, the clearly concentrated psychological type preference within the group can flourish and be given clear expression. Second, operating in this context, the voice of the sensing function emerges clearly as being concerned with the actual material that is there before them on the page. Here are people who are concerned with detail and with getting the picture clearly established. Third, operating in this context, the voice of the intuitive function emerges clearly as being concerned with the bigger picture, with the wider possibilities, with the manifold connections that emerge from the material there before them on the page. Here are people who enjoy sparking ideas off each other and who are more concerned with generating new approaches rather than seeing them through to conclusion. Fourth, operating in this context, the voice of the feeling function emerges clearly as being concerned with the underlying values, relationships, and human experience at the heart of the text. Here are people whose hearts are touched by the scriptures and who are seeking for signs of God's love and mercy. Fifth, operating in this context, the voice of the thinking function emerges clearly as being concerned with the issues of logic and coherence raised by the text. Here are people whose minds are stretched by the scriptures and who are seeking for evidence of God's truth and justice. These five main points focus questions about the community aspect of the revelatory encounter between the reader and the sacred text. Building on these findings, the SIFT approach to biblical hermeneutics and liturgical preaching suggests that the sacred text is received most powerfully when readers (whose voices are shaped by the diversity of psychological type functions) share their respective insights one with another.

\section{Research Aim}

Although the cumulative evidence emerging from these studies is consistent and persuasive, the generalisability of the findings is limited by the way in which the majority of the studies have been conducted among trained and experienced preachers who are already well versed in the Christian scriptures. The present study extends the research tradition among a group of Muslim educators. A conference of Muslim educators provided a context in which to test how psychological type preferences may be reflected in reading scripture among a group of people interested in religious text that has some similarities with the Divine revelation within the Muslim tradition, but not necessarily directly familiar with the scriptures within the Judean-Christian tradition. As an initial exercise in this research tradition it was decided to explore Psalm 1 and to focus on the judging process (thinking and feeling), in a way that would clarify the potentially distinctive approaches of participants who expressed a clear preference for thinking and participants who expressed a clear preference for feeling.

\section{Method}

The study was carried out within the context of an annual Islamic Education summer school organised in the UK that explored challenges facing Muslim educators working within diverse Muslim communities across Europe. The Muslim educators attending the event belonged to diverse Sunnni Muslim communities settled in several western European countries. They had Islamic Studies and theological educational backgrounds and most of them were also trained teachers and some were clergy, imams, leading prayers in the Mosques in their communities. Most of them were involved in teaching Islam within community-based Islamic educational settings such as madrassahs/maktabs, Islamic schools as well as mainstream schools in their respective countries. A full half-day in the programme was dedicated to exploring the connections between the theology of individual differences, biblical hermeneutics and empirical theology. Two components of psychological type theory were explored, the two orientations (introversion and extraversion) and the two judging functions (thinking and feeling). Individual readings of psychological type preferences were taken by the Francis Psychological Type Scales (Francis 2005). On the basis of scores recorded on thinking and feeling the 22 participants were divided into three groups: seven participants who had identified themselves as having a clear preference for feeling, eight participants who had identified themselves as having a clear preference for thinking, and seven participants who has less clear preferences. Before 
dividing into the three groups, Psalm 1 was read aloud and the task clearly voiced: 'What issues in this passage touch your heart and stretch your mind?' Each group was asked to identify one person to take notes and to feed back in the plenary session. Since the aim of the study was to clarify the potentially distinctive approaches of participants who expressed a clear preference for thinking and participants who expressed a clear preference for feeling, one observer joined the group comprising those with clear preference for feeling and a second observer joined the group comprising those with a clear preference for thinking in order to note the conversation and behaviour carefully. The subsequent analysis is provided by these two observers. As is customary in studies of this nature, the third group (in which clarity of preference on the judging process was not declared) was neither observed nor reported.

\section{Results}

\subsection{Feeling}

There were seven participants (and one observer) in the group of individuals who had identified themselves as having a clear preference for feeling. Psalm 1 proved to be challenging and uncomfortable for this group. There was such urgency in dealing with this sense of discomfort that the group invested immediately in the task, without wasting time either to reflect on how they would conduct their conversation or to appoint someone who would report back to the plenary session. The first person to speak was curious about the origin of the passage. Unfamiliar with the Christian scripture, she asked where this passage could be found in Jesus' teaching. This led to some conversation about the book of Psalms by a religious educator in the group, and a wider reference to the Book of Job. Not allowing herself to be distracted by this information, the first person to speak went on to say that she found the claim that sinners are not going to stand in the congregation difficult and distressing. For her the narrative of the fruitful tree always bringing forth goodness was comforting, but surely sinners also needed to be there in the congregation with the fruitful trees to benefit from their goodness. From this very opening point onwards there was a clear attempt to find ways to soften the apparent tough message in the Psalm.

The second person to speak felt uncomfortable with the radical distinction, because in reality we just cannot classify people in that way. He argued that in most religions there is a tendency to create polar opposites. White becomes whiter and black becomes blacker. However, this exaggeration is done to make a point. The point is to motivate us to be good. The contrast is offered to give us guidance. God does not think in black or white terms like this. There are times when we fall in between the black and the white. We stumble, but God always guides us to the good.

The first participant was not yet convinced. For her the passage remained too judgemental: 'This passage really makes me pull my head back. This is not what religion is about. It really upsets me. I think sinners should be invited into the congregation, not pushed away.'

The third person to speak tried to soften the passage in another way. For him this Psalm speaks powerfully because it re-affirms the individual's responsibility, autonomy, and choices. It shows that choices have consequences. God has not chosen the outcome for you, but you have chosen it for yourself. In addition, God has mercy.

The first participant was still not convinced. 'This passage scares me because I question where I belong, with the sinners or with the righteous? And I am questioning where is the mercy? We do not like to see a God who is only a just God.'

The fourth person tried to draw on his Islamic heritage. 'As a Muslim I know that we cannot give the whole Qur'an in one passage. We need these passages to strengthen our faith. You cannot have mercy without justice. Mercy is stronger than justice.'

The first participant was still not convinced. She recognised that drawing on her life experience can help her deal with the passage, but she still found it dangerous. 'To give this passage to a child is dangerous. For young children things are either black or white. They don't have the subtlety. With my 
own children I will only refer to those attributes of God later on. I really think God is merciful and that is more important than judgement.'

Then the fifth participant intervened and cracked the problem. She had been silent for some time reading and reflecting on the passage. The passage concludes by saying that 'The Lord watches over the way of the righteous. But the way of the wicked will perish.' The emphasis here is not on the people, but on what they do: 'It is not the people who are being condemned. Today in school you condemn not the pupils but the things that they do.'

This intervention lightened the whole mood of the group. It felt as if a weight had been lifted, as if the hurt had been eased. Now the first participant physically relaxed as if the pressure was off. It was as if the group had now really cracked the secret of Psalm 1 and that secret was consistent with their strong commitment to the God of mercy.

In the feeling generated by the discussion this group of feeling types seemed to have lost touch with the sense of time and were taken by surprise when they were called back into the plenary session. A slight sense of panic took over as they tried to re-group to prepare a presentation.

\subsection{Thinking}

There were eight participants (and one observer) in the group of individuals who identified themselves as having a clear preference for thinking. The participants were energised by the task and began their work on the way to the breakout room. As soon as the room was entered they moved chairs into a circle and began work in earnest. The first participant, a teacher within the group, produced a flip chart and pen and offered to assume the role of noting the discussion points and feeding back to the main group. Then the second participant intervened with the suggestion that they should pause and re-read the passage in silence. The group was well organised.

The strategy of re-reading the Psalm was wise, because it highlighted the way in which the poetic language was less accessible to some participants who were not native English speakers, including 'scoffers' and 'chaff'. Time taken for explanation was time well invested. Right from the start the group seemed aware of the core issues raised by the passage and rose to the challenge of dealing with the issue head on. 'Here', said the third participant, 'is an issue that touches the mind and we need to deal with it.'

In what may have been an attempt to deflect attention from the core challenge of the passage, the second participant intervened again: 'The Psalm inspires one to be encouraged/inspired to remain faithful.' He was quickly challenged by others to explain what he meant.

The third participant returned to the conversation and suggested that the passage connects with Qur'anic imagery: 'It's a text for thinkers, a text about righteousness. The text is firm. It puts forward a moral choice to make. There is no grey zone. And you have to be prepared for the consequences of your choices. You will perish—very absolute and very hard.' This point met with general agreement within the group, with one dissenter. The third participant went on to develop his point and to apply clear thinking analysis. Here is a passage that sets out contrast: 'righteous verses sinners-you choose your path-if you follow sinners you are doomed-if you are righteous you are faithful. But out of context and in the hands of the wrong person the text could be dangerous.'

The third participant proceeded to push the binary choice more forcefully and clarified the contrast further: 'On the positive side, those who do good are affirmed through beautiful language. They are like trees planted by streams of water, and even their leaves do not wither. By contrast the sentence for sinners is brief and abrupt. This structure makes readers decide that they have to make a decision on their conduct.'

Again in what may have been a second attempt to deflect attention from the core challenge of the passage (as being voiced by the group), the second participant injected that it is not so easy to follow a binary divide between good people and sinners. According to this participant, the use of 'happy' as the very first word of the Psalm made the whole Psalm a promise. It creates a motivation, a beautiful motivation to want to be like the good trees planted by the stream. 
The third participant was not convinced by the intervention and drew on Qur'anic material, suggesting the use of the rhetorical and metaphorical language in the Qur'an in order to illustrate the certain core moral points and lessons to be learned: 'The Qur'an has some binary texts like these. The reader is told to look at the scenario, to think about it, and to reflect on where you will fall. But there is a way back for the wicked.' This participant went on to argue that religious educators need to be better equipped to deal with texts like this: 'As leaders we have to give both sides, both scenarios. We need a pedagogic tool to put two opposing positions together and to help us to work out the lessons we need to take from texts like this.'

By the time that they were called back into the plenary session this group of thinking types were well prepared. Their discussion had been well organised and structured on the flip chart to make an even more coherent presentation than had emerged in the session itself. However, the conversation had not ended when they left the breakout room. Ongoing conversation on the walk back to the plenary session allowed one member of the group to formulate the obvious logical outcome of the workshop. After the planned script had been presented from the flip chart he concluded the presentation by saying: 'The power that could emanate from the passage is enormous. If you want to go to heaven you must drive the wicked out. Here is the mandate for extremism. If you think you are doing the Lord's work become a suicide bomber. We need a more mature way of teaching about God than texts like this!'

\section{Discussion}

The present study was intentionally conceptualised and operationalised with theoretical and empirical contexts shaped and established within the Christian tradition. As a consequence the contextualisation for the study did not engage directly with the field of Qur'anic hermeneutics. Having now explored and illustrated how the SIFT approach to biblical hermeneutics engaged Islamic educators in dialogue with Psalm 1, it is appropriate to engage briefly with the broader literature on and with recent developments in Qur'anic hermeneutics.

The notion of Divine revelation is central to the three Abrahamic traditions of Judaism, Christianity, and Islam. While each faith has a distinctive self-perception of Divine revelation and scared scriptures, all have produced rich exegetical and hermeneutical heritages around the Divine Word. In Judaism and Christianity the interpretive engagement with the sacred scriptures has gradually shifted from placing the focus of attention on the text, on its historical context sitz im leben, and on the intentions of the author, to focusing attention more closely on the readers and on their personal profile and social context as factors that have significant bearings on the acts of receiving and responding to the sacred discourses and revelation. The development of this approach to the scripture in the Judaeo-Christian tradition on the reader-focused approach has generated as a natural outcome lay or public theologies.

In Muslim tradition, the stress on Divine revelation as the literal word of God and the strict rules governing exegesis, commentary (tafsir/ta'wil) and legal hermeneutics (ijtihad) laid down within the tradition have often been seen as rendering a reader-focused engagement with the scripture as unthinkable, even among the Muslim faith leaders and educators (Sahin 2013). This study has examined the validity of such often taken-for-granted assumption about Muslim attitudes towards direct personal engagement with sacred scripture. The approach grounded in psychological type theory to scriptural hermeneutics (that has been widely used within the Christian context) offers a rigorous theoretical and practical framework to explore Muslim faith leaders' and Muslim educators' willingness to engage with personal interpretations of sacred scriptures and to construe personally meaningful insights from the text. Due to the understandable sensitivity over the negative implications associated with the notion of the 'personal interpretation of the sacred scripture' within the Muslim tradition, it was decided to select a biblical text that can easily resonate with Muslim readers as the content, message and imagery used will have some parallels within the core Muslim sources (the Qur'an and the prophetic reports known as Hadith) rather than directly select a Qur'anic text for this 
initial exploratory study. These findings, however, nonetheless resonate with some current trends in Qur'anic hermeneutics.

There are plethora of studies exploring classical traditions of Qur'an exegesis and interpretation (tafsir/ta'wil) (Rippin 2012; Wild 1996; Saeed 2006; Esac 1996). Recently, the traditional and most dominant single verse-based exegetical tradition has come under criticism as this 'atomistic and isolated' readings of the text have claimed to be hindering the grasp of holistic understanding of the Qur'an and its overall message. As an alternative, scholars like Rahman (1994) have invoked the traditional genre of reflective/reason-based Qur'an exegesis known as 'diraya' and has advocated a more contextual-reflective Qur'anic hermeneutics that stresses the significance of modern recipients /readers' reality in understanding the Qur'an's worldview and generating personal inspirations and guidance. Rahman's work has been influential in the development of what can be characterised as an emerging feminist interpretations of the Qur'an (Wadud 1999; Barlas 2002; Mernissi 1991).

Sahin (2014) also draws attention to the presence of an overwhelmingly legal and political interpretations of the Qur'an where certain readings are privileged as representing the 'true authorial intentions' that simply need to be followed without questioning. These legal and political interpretations, which often tend to exhibit features of an ahistorical literalism, have been countered by mystical or theosophical hermeneutics where the emphasis on the allegorical and philosophical interpretation have almost left no room to recognising the normative meanings discerned by the transmitted living tradition from the Qur'an across generations. Sahin $(2014,2016,2017)$, in order to overcome this incompatible divergence and rigid ideological literalism, calls for emergence of the application of 'a critical educational hermeneutics' to the Qur'an where the process of interpretation is based on dialogical engagement between the reader and text which in turn generates distinctive understandings, meanings and guidance that are embedded within the Qur'an and within wider Muslim tradition and that are articulated through the personal reality of the readers. This person-embedded and text-focused interpretative process ultimately facilitates the empowerment of the reader. By using the theoretical framework of personal construct psychology, developmental psychology and Muslim theology, Sahin $(2014,2016)$ has constructed an empirical measurement protocol, Muslim Subjectivity Interview Schedule, to explore formation of individual religiosities among Muslim young people and illustrate how such a reflective educational hermeneutics can nurture the religious agency of Muslim young people, while directly encountering the sacred discourse.

Furthermore, there are some small scale recent research studies such as Grung (2015) carried out as part of scriptural reasoning exercises within the context of interfaith dialogue and intertextual discussions exploring topical issues such as depictions of women (gender-justice) within the Bible, the Qur'an and the prophetic reports (the Hadith). This small scale study included few Muslim participants. However, with reference to the current study, psychological type theory had not previously been introduced to Qur'anic hermeneutics and this is the first attempt to examine its suitability with Muslim faith leaders and Muslim educators.

It must be noted that the empirical study of contemporary Muslim religiosities is still in its early stages of development. However, due to increasing political debates about modern Islam, illustrated with the discussions around radicalisation, political Islam etc., social scientists working mainly within sociology, politics and religious studies, have focused their attention on understanding the formation of collective religious identities, sense of solidarity and belonging within diverse contemporary transnational Islamic movements such as Salafiis, Sufis, Deobandis, Jamaat-e Islami and Al-Ikhwan Al-Muslimuun etc. The analysis in these studies appears to be confined to exploring the main features and dynamics shaping the collective identities within these religious movements. They often employ socio-political categories such as conservative, ultra-conservative, reformist, fundamentalist, spiritual, liberal etc. to define these group identities. Even the theologically significant concepts like 'scripture' and 'spiritual' are utilised as anthropological concepts to discern patterns of culturally-based Islamic interpretations and experiences. This line of research goes back to the seminal work by Geertz (1971) whose anthropological observations in Morocco and Indonesia gave us an 
often used typology of Muslim religiosity i.e., a scripturally-focused austere, reformist Islam and more populist, spiritually-inclined syncretic Islamic expressions that include non-Islamic cultural elements in these societies.

The focus in the current study was not to explore participants' religiosity as such or the religiosities of the movements they belonged to but look at the relationship between psychological type and the process of interpreting the scriptures. The intention was not look at how participants' specific religious/spiritual traditions shape their individual interpretations of the scripture. One could easily associate belonging to a spiritual movement, like Sufism, with the feature of a feeling type personality whereas a more scripture-focused movement like that of the Salafis with the features of a thinking type personality. This interesting line of research needs to be taken up by a separate study.

The Muslim educators who participated in this study came from a broad Sunni Islamic background and had affiliations with diverse types of contemporary Islamic movements and groups. They all had Islamic theological study and training and some were faith leaders, imams, leading prayers in the mosques within their communities Therefore, they were familiar with the traditional Qur'anic sciences including the science of Qur'anic interpretation (Tafsir). Furthermore, they were aware that Islam acknowledges diversity of sacred scriptures sent by God and recognises Jewish and Christine communities as 'people of the Book'. As such, the participants did not show any concern in reading and engaging with Psalm 1 and recognised it as a piece of scripture. There was no sign of any ideologically motivated rigid attitude towards interacting with a piece of biblical scripture. In fact, as reported above, they recognised that similar content and categories of people have been presented in the Qur'an too and naturally engaged with a form of intertextual reflection.

\section{Conclusions}

The SIFT approach to biblical hermeneutics and liturgical preaching, rooted in psychological type theory, has been developed and tested by a series of empirical studies within the Christian community among participants familiar both with the Christian scriptures and with conventional Christian modes of biblical hermeneutics and liturgical proclamation. The present study set out to extend this research tradition among a group of Muslim educators. The passage of scripture selected was Psalm 1. As anticipated, many of these participants were unfamiliar both with the specific Psalm and with the wider genre of that form of biblical literature. However, the content, imagery and messages contained within the Psalm generated resonance with several similar Qur'anic passages that the participants brought to bear in the discussion. The findings from the study demonstrated clear differences between the ways in which thinking types and feeling types handled the judgement metred out to the wicked in the Psalm. Feeling types were disturbed by the portrayal of God in this Psalm and sought ways to mitigate the stark message. Thinking types confronted the dangers to which this image of God could lead and sought pedagogic strategies for dealing with these dangers.

By drawing on Muslim educators these data have strengthened the empirical evidence on which the SIFT approach to biblical hermeneutics and liturgical preaching has been grounded. The present study has been limited in two ways. Not only was the study limited to one passage of scripture, but it also concentrated on just one of the two core processes identified by psychological type theory (the judging process distinguishing between thinking and feeling). There remains scope, therefore, for future studies working among Muslim educators to draw on other examples from the Christian scriptures and to explore the perceiving process (distinguishing between sensing and intuition) as well as the judging process.

More significantly, these new findings strongly indicate the need to apply the SIFT hermeneutical approach with diverse groups of Muslim faith leaders, educators and lay people while directly engaging with the Qur'an and with the prophetic reports (the Hadith). By facilitating reflective textual engagement such empirical studies will make an original contribution to the growing interdisciplinary field of Islamic Education Studies as well as help develop an empirical approach within modern Qur'anic hermeneutics and Qur'anic studies. 
Author Contributions: L.J.F conceptualised the research problem and shaped the analytical Model. A.S rooted the research question within the fields of Qur'anic hermeneutics and Islamic Education Studies. U.M and L.J.F jointly captured and analysed the data.

Funding: This research received no external funding.

Conflicts of Interest: The authors declare no conflict of interest.

\section{Appendix A}

\section{Psalm 1}

Happy are those who do not follow the advice of the wicked, or take the path that sinners tread, or sit in the seat of scoffers.

However, their delight is in the law of the Lord, and on his law they meditate day and night.

They are like trees planted by streams of water, which yield their fruit in its season, and their leaves do not wither; in all that they do, they prosper.

The wicked are not so, but are like chaff that the wind drives away.

Therefore the wicked will not stand in the judgment, nor sinners in the congregation of the righteous; for the Lord watches over the way of the righteous. However, the way of the wicked will perish.

What issues in this passage touch your heart and stretch your mind?

\section{References}

Barlas, Asima. 2002. Believing Women in Islam: Unreading Patriarchal Interpretations of the Qur'an. London: University of Texas Press.

Botta, Alejandro F., and Pablo R. Andiňach, eds. 2009. The Bible and the Hermeneutics of Liberation. Leiden: Brill.

Brown, Michael J. 2004. Blackening of the Bible: The Aims of African American Biblical Scholarship. London: Continuum.

Chaim, Wladyslaw. 2013. Typy psychologiczne w recepcji i przekazie slowa bożego [Psychological typology in the reception and transmission of the Word of God]. Roczniki Pastoralno-Katechetyczne 5: 155-70.

Chaim, Wladyslaw. 2014. Metoda interpretacji i przepowiadania slowa bożego SIFT w slużbie kaznodziejstwa cala dusza [The SIFT method in the service of preaching with all our souls]. Roczniki Teologiczne 61: 117-36.

Chaim, Wladyslaw. 2015. Profil typu psychologicznego, interpretacja biblii I głoszenie słowa bożego (badania empiryczne) [Psychological type profile, biblical hermeneutics and liturgical preaching (empirical research)]. Resovia Sacra 22: 45-69.

Esac, Farid. 1996. Qur'an, Liberation and Pluralism: An Islamic Perspective of Interreligious Solidarity against Oppression. London: Oneworld Publications.

Francis, Leslie J. 1997. Personality Type and Scripture: Exploring Mark's Gospel. London: Mowbray.

Francis, Leslie J. 2005. Faith and Psychology: Personality, Religion and the Individual. London: Darton, Longman and Todd. Francis, Leslie J. 2010. Five loaves and two fishes: An empirical study in psychological type and biblical hermeneutics among Anglican preachers. HTS Theological Studies 66: 1-5. [CrossRef]

Francis, Leslie J. 2012a. What happened to the fig tree? An empirical study in psychological type and biblical hermeneutics. Mental Health, Religion and Culture 15: 873-91. [CrossRef]

Francis, Leslie J. 2012b. Interpreting and responding to the Johannine feeding narrative: An empirical study in the SIFT hermeneutical method among Anglican ministry training candidates. HTS Theological Studies 68: 1-9. [CrossRef] 
Francis, Leslie J. 2013. Ordinary readers and reader perspectives on sacred texts: Drawing on empirical theology and Jungian psychology. In Exploring Ordinary Theology: Everyday Christian Believing and the Church. Edited by Jeff Astley and Leslie J. Francis. Farnham: Ashgate, pp. 87-96.

Francis, Leslie J. 2015. Footwashing and diaconal ordination. In The Farewell Discourses in Practice. Edited by John Vincent. Blandford Forum: Deo Publishing, pp. 21-28.

Francis, Leslie J., and Tania ap Siôn. 2016a. Jesus, psychological type and conflict: A study in biblical hermeneutics applying the reader perspective and SIFT approach to Mark 11: 11-21. HTS Theological Studies 72: 1-9. [CrossRef]

Francis, Leslie J., and Tania ap Siôn. 2016b. Empirical theology and biblical hermeneutics: Exploring lessons for discipleship from the Road to Emmaus (Luke 24: 13-35). Journal of Empirical Theology 29: 24-44. [CrossRef]

Francis, Leslie J., and Tania ap Siôn. 2017. Reading the Lucan call of the first disciples differently: The voices of sensing and intuition. Journal of Beliefs and Values 38: 188-98. [CrossRef]

Francis, Leslie J., and Peter Atkins. 2000. Exploring Luke's Gospel: A Guide to the Gospel Readings in the Revised Common Lectionary. London: Mowbray.

Francis, Leslie J., and Peter Atkins. 2001. Exploring Matthew's Gospel: A Guide to the Gospel Readings in the Revised Common Lectionary. London: Mowbray.

Francis, Leslie J., and Peter Atkins. 2002. Exploring Mark's Gospel: An Aid for Readers and Preachers Using Year B of the Revised Common Lectionary. London: Continuum.

Francis, Leslie J., and Susan H. Jones. 2011. Reading and proclaiming the resurrection: An empirical study in psychological type theory among ministry training and experienced preachers employing Mark 16 and Matthew 28. Journal of Empirical Theology 24: 1-18. [CrossRef]

Francis, Leslie J., and Susan H. Jones. 2014. Life in the eucharistic community: An empirical study in psychological type theory and biblical hermeneutics reading John 6: 5-15. Pastoral Psychology 63: 281-90. [CrossRef]

Francis, Leslie J., and Susan H. Jones. 2015a. An empirical approach to Mark's account of discipleship: Conversation between the Word of God and the People of God. Rural Theology 13: 69-81. [CrossRef]

Francis, Leslie J., and Susan H. Jones. 2015b. Preparing for Disability Awareness Sunday: An educational exercise drawing on psychological perspectives for biblical hermeneutics. International Journal of Christianity and Education 19: 197-214. [CrossRef]

Francis, Leslie J., and Greg Smith. 2012. Separating sheep from goats: Using psychological type theory in a preaching workshop on Matthew 25: 31-46. Journal of Adult Theological Education 9: 175-91. [CrossRef]

Francis, Leslie J., and Greg Smith. 2013. Reading and proclaiming the Birth Narratives from Luke and Matthew: A study in empirical theology among curates and their training incumbents employing the SIFT method. HTS Theological Studies 69: 1-13. [CrossRef]

Francis, Leslie J., and Greg Smith. 2014. Reading and proclaiming the Advent call of John the Baptist: An empirical enquiry employing the SIFT method. HTS Theological Studies 70: 1-9. [CrossRef]

Francis, Leslie J., and Greg Smith. 2017. Learning relationships: Church of England curates and training incumbents applying the SIFT approach to the Road to Emmaus. HTS Theological Studies 73: 1-11. [CrossRef]

Francis, Leslie J., and Andrew Village. 2008. Preaching with All Our Souls. London: Continuum.

Francis, Leslie J., Greg Smith, and Guli Francis-Dehqani. 2017. The missionary journey of Mark 6 and the experience of ministry in today's world: An empirical study in biblical hermeneutics among Anglican clergy. HTS Theological Studies 73: 1-7. [CrossRef]

Geertz, Gilford. 1971. Islam Observed: Religious Development in Morocco and Indonesia. London: University of Chicago Press.

Grung, Anne Hege. 2015. Gender Justice in Muslim-Christian Readings. Amsterdam: Brill Rodopi.

Jung, Carl G. 1971. Psychological Types: The Collected Works. London: Routledge and Kegan Paul, vol. 6.

Mernissi, Fatema. 1991. Women and Islam: An Historical and Theological Enquiry. London: Blackwell.

Myers, Isabel. B., and Mary H. McCaulley. 1985. Manual: A Guide to the Development and Use of the Myers-Briggs Type Indicator. Palo Alto: Consulting Psychologists Press.

Rahman, Fazlur. 1994. Major Themes of the Qur'an. Minneapolis: Bibliotheca Islamica.

Rippin, Andrew. 2012. Approaches to the History of the Interpretation of the Qur'an. London: Gorgias Press.

Saeed, Abdullah. 2006. Interpreting the Qur'an: Towards a Contemporary Approach. London: Routledge. 
Sahin, Abdullah. 2013. Authority and autonomy: An Islamic education perspective on human agency. In Negotiating Autonomy and Authority in Muslim Contexts. Edited by Marjo Buitelaar and Monique Bernards. Leuven: Peeters, pp. 67-85.

Sahin, Abdullah. 2014. New Directions in Islamic Education: Pedagogy and Identity Formation. Markfield: Kube Academic. Sahin, Abdullah. 2016. The future of Islamic education: A case for reform. RE Today 33: 61-65.

Sahin, Abdullah. 2017. Religious literacy, interfaith learning and civic education in pluralistic societies: An Islamic educational perspective. In Interfaith Education for All: Theoretical Perspectives and Best Practices for Transformative Action. Edited by Duncan R. Wielzen and Ina ter Avest. Boston: Sense Publishers, pp. 45-53. Schottroff, Luise, and Marie-Theres Wacker, eds. 2012. Feminist Biblical Interpretation: A Compendium of Critical Commentary on the Books of the Bible and Related Literature. Grand Rapids: Eerdmans.

Segovia, Fernando F., and Mary A. Tolbert, eds. 1995a. Reading from This Place: Social Location and Biblical Interpretation in the United States. Minneapolis: Fortress Press.

Segovia, Fernando F., and Mary A. Tolbert, eds. 1995b. Readings from this Place: Social Location and Biblical Interpretation in Global Perspective. Minneapolis: Fortress Press.

Smith, Greg, and Leslie J. Francis. 2016. Difficult texts: Mark 10: 46-52. Theology 119: 200-3. [CrossRef]

Wadud, Amina. 1999. Qur'an and Woman: Rereading the Sacred Text from a Woman's Perspective. Oxford: Oxford University Press.

Wild, Stefan. 1996. The Qur'an as Text. Leiden: E.J. Brill.

(C) 2018 by the authors. Licensee MDPI, Basel, Switzerland. This article is an open access article distributed under the terms and conditions of the Creative Commons Attribution (CC BY) license (http:/ / creativecommons.org/licenses/by/4.0/). 